\title{
SRI LANKA: THE GEM ISLAND
}

\author{
By Peter C. Zwaan
}

Sri Lanka, formerly Ceylon, remains one of the single most important sources for fine gemstones. Especially notable are blue sapphire, pink sapphire or ruby, and yellow sapphire; alexandrite and cat's-eye chrysoberyl; and almandite and hessonite garnet. Spinel, tourmaline, zircon, moonstone, and quartz are also relatively common; they share their country of origin with several rarer gemstones as well. Most of the gem-quality material is found in alluvial deposits throughout the island, which are mined by primitive methods. In many instances, the Sri Lankan origin of the gemstone can be determined by characteristic inclusions, several of which are also discussed in this article.

\section{ABOUT THE AUTHOR}

Prolessor Zwaan is director of the National Museum of Geology and Mineralogy, Leiden, Netherlands.

Acknowledgments: The author is much indebted to Mr. W. A. M. Devilé, photographer of the National Museum of Geology and Mineralogy at Leiden, for the preparation of figures $3,6,11,12$, 13, and 14.

This article was developed from a paper presented at the International Gemological Symposium in Los Angeles, California, February 1982.

"1982 Gemological Institute of America $\prod$ he gem riches of Sri Lanka have been legendary for Nearchus, who in 334 B.C. mentioned an island not far from Persia where beautiful translucent gems had been found. Without a doubt, this island was the present Sri Lanka. Much later, at the beginning of the 16th century, Portuguese sailors discovered the island and returned to Europe with some of its gemstones; seamen from Holland did the same some hundred years later.

Over the centuries, tens-probably hundreds-of thousands of carats of fine sapphire, ruby, chrysoberyl, spinel, and other familiar as well as unusual gemstones have been mined in Sri Lanka. Yet many questions continue to surround the geology of the deposits, and mining methods remain, for the most part, very primitive.

During the course of the author's eight trips to Sri Lanka, he has traveled all over the country and inspected the major mining areas-beginning in 1958 with the historically important Ratnapura area and completing most recently, in February and November of 1981, a study of the newer Tissamaharama area.

The author has drawn from his experiences and investigations to provide this overview of the geology of Sri Lanka and its mining and cutting practices, as well as special features of the various gem materials found there. Also examined are inclusions characteristic of Sri Lankan gemstones and production figures for the area.

\section{GEOLOGY}

Sri Lanka is one of the most important localities for gemstones in the world. Almost all of these gems, however, occur in alluvial deposits, and their original source remains unknown today.

A geologic sketchmap (figure 1) shows that the island is almost entirely underlain by Precambrian rocks. These rocks can be divided into three groups based on their lithology, structure, and age, as described below. 


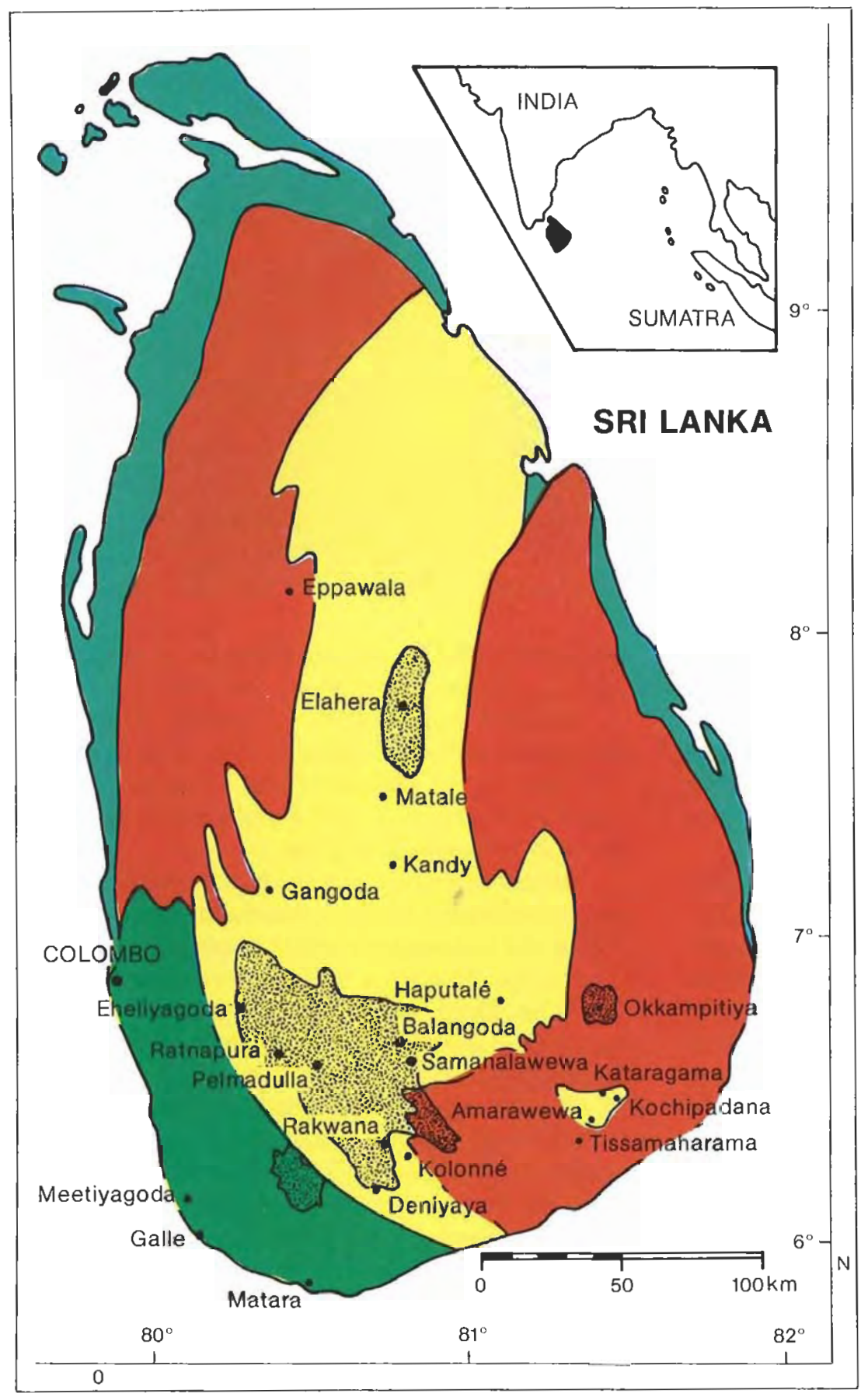

Figure 1. Geological sketchmap of Sri Lanka, with the main gemproducing areas identified.

CENOZOIC
PRECAMBRIAN
HIGHLAND GROUP
VIJAYAN COMPLEX
SOUTHWEST GROUP
GEM MINING AREAS

The oldest unit on the island is the Highland group, which contains rocks of the metamorphic granulite facies, such as hypersthene gneisses (chamockites), sillimanite-garnet gneisses (khondalites|, biotite-garnet gneisses, and marbles in which forsterite and spinel occur. Most of the gem deposits are located within this group.

The second unit is the Vijayan complex. This unit is characterized by rocks of the almandite- amphibolite facies, such as biotite-hornblende gneisses.

The overlying Southwest group consists of rocks that belong to the cordierite-granulite facies. It contains both cordierite gneisses and khondalites.

Although most of these rocks, as well as numerous pegmatites found throughout the country, contain gem materials, it is remarkable that 


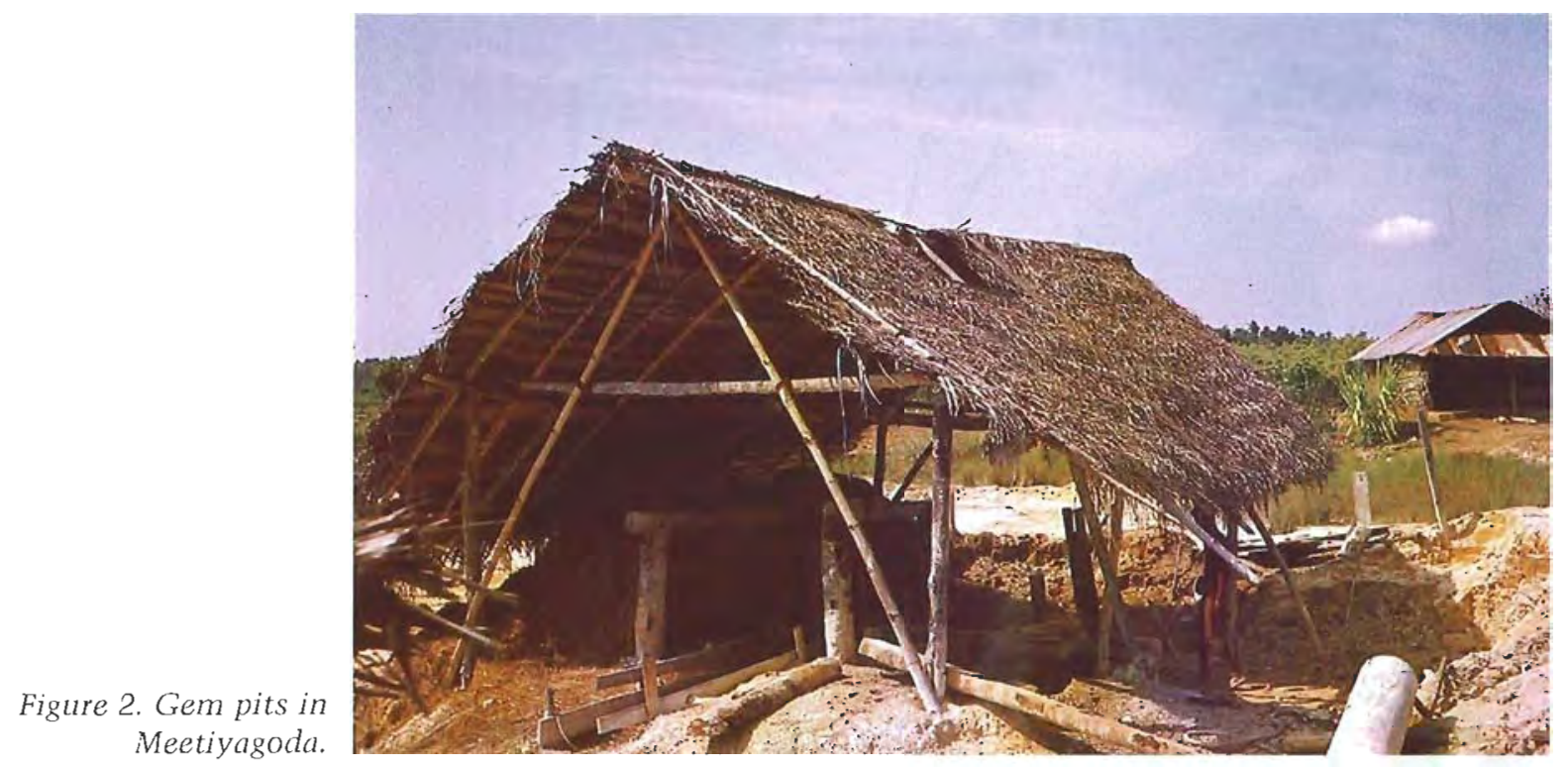

few of the minerals found thus far in situ are of gem quality. Yet numerous alluvial deposits on the island contain pebbles of the same gem minerals, many of which are of gem quality. There is no doubt that the latter originated in rocks not far from their present localities, but up to now the host rocks have not been found.

It would be particularly interesting to establish the original source of blue sapphire, the most important gemstone in Sri Lanka. The only known location of gem-quality blue sapphire in situ is in a pegmatite located near Kolonné in the Ratnapura district, where the blue sapphire is found together with diopside (Gunaratne, 1976). The only other gemstones found in host rock are moonstone, which occurs in Meetiyagoda, near Galle, and some almandite garnet, which occurs in several places throughout the island.

\section{GEM DEPOSITS}

As mentioned above, almost all of the gem-quality minerals from Sri Lanka occur in alluvial deposits; the main gem-bearing area is the Ratnapura district in Sabaragamuwa Province, some 97 $\mathrm{km}$ (60 miles) southeast of Colombo. The gems are concentrated in more-or-less horizontal layers at different depths in the alluvium, which consists primarily of sand and gravel. The most notable localities are Ratnapura / the name means "city of gems"), Pelmadulla, Balangoda, and Rakwana.

Similar deposits are found near Elahera in the Central Province, in particular in the valley of the Kaluganga River. Here, the gem minerals are not concentrated in specific levels, but are almost uniformly distributed throughout in a lateriterich deposit of sandy gravel and clay.

Another gem deposit of interest is near Okkampitiya in the province of Uva. This deposit is very similar in appearance to those in the Ratnapura district. It is well known for its large production of hessonite garnet.

About three years ago, gem-bearing deposits were discovered in the Tissamaharama area (also called the Kataragama area) in Southern Province. The major localities are Amarawewa, about 10 $\mathrm{km}$ from Tissamaharama in the direction of Kataragama; and Kochipadana, about $5 \mathrm{~km}$ east of Kataragama. In this region, gem minerals occur in alluvial deposits at a depth of about $1 \mathrm{~m}$.

Although certain areas in Sri Lanka may be wetter than others, it is usually not difficult to visit the various gem-mining districts. The traveler is advised, however, to ask the assistance of the State Gem Corporation in arranging a guide, a necessity for every foreigner and particularly so for the first-time visitor. The author was cautioned to exercise some care when visiting the Elahera district, but his personal experience with the people there was very good.

\section{GEM MINING}

Gem mining in Sri Lanka is primitive. Usually, pits are dug to the depth of the gem-bearing gravel layer. Depending on the level of the groundwater, and on whether the area is wet or dry, some method of drainage is used. The pits are strengthened with wooden bulwarks to avoid caving. The workers are protected from the sun by a thatched roof (figure 2). 
It is not unusual for some of the deeper pits to extend a short tunnel from the bottom, although such a tunnel is dangerous, especially in wet areas like the Ratnapura district. In this area, pits vary in depth from 5 to $15 \mathrm{~m}$. The gem rough is very rounded, which indicates either intensive rolling or long transport.

In the Elahera area, the depth of the gem-bearing gravel ranges from about 3 to $9 \mathrm{~m}$. Mining is less complicated than in the Ratnapura district because this part of Sri Lanka is very dry. Although the gem minerals in the laterite-rich deposits are rounded only slightly, distinct, welldeveloped crystal faces are seldom seen.

In the Tissamaharama area, not only is the material rounded only very little, but many specimens (in particular, corundum and tourmaline) have well-developed crystal faces (figure 3). It is apparent that these crystals have been transported by nature a considerably shorter distance than gem minerals found elsewhere in Sri Lanka, which suggests that their original source is relatively close.

In all of the gem deposits, the gem-bearing gravel, which is locally called illam, is placed in baskets that are usually hoisted up from the pit by means of a rope. Large quantities of this illam are heaped near the pit.

To wash the gravel, the worker stands waist deep in muddy water, shaking and rotating a cone-

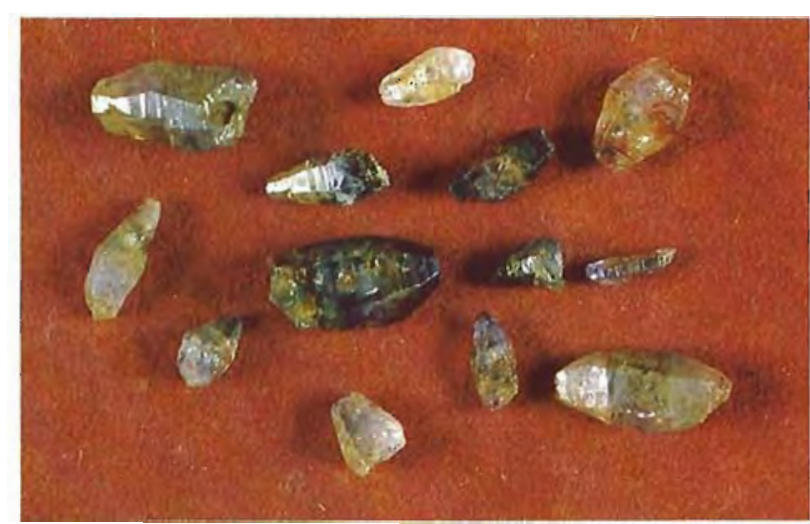

Figure 3. Corundum crystals from Kochipadana. For scale note that the crystal in the center at the bottom is $17 \mathrm{~mm}$ long and weighs $14.9 \mathrm{ct}$.

shaped, plaited basket (figure 4). Recovery rates are thought to be quite high with this method. In a short time, most of the mud is washed away, and the larger pebbles, most often opaque or translucent, are picked out and thrown away. After further swirling, the washed gravel, which is locally called dullam, is examined for gemquality material by the supervisor; in most cases, this is the owner of the mine.

\section{LAPIDARY TREATMENT}

Cutting is done by means of a wooden apparatus that has a horizontal axis and a vertical wheel at

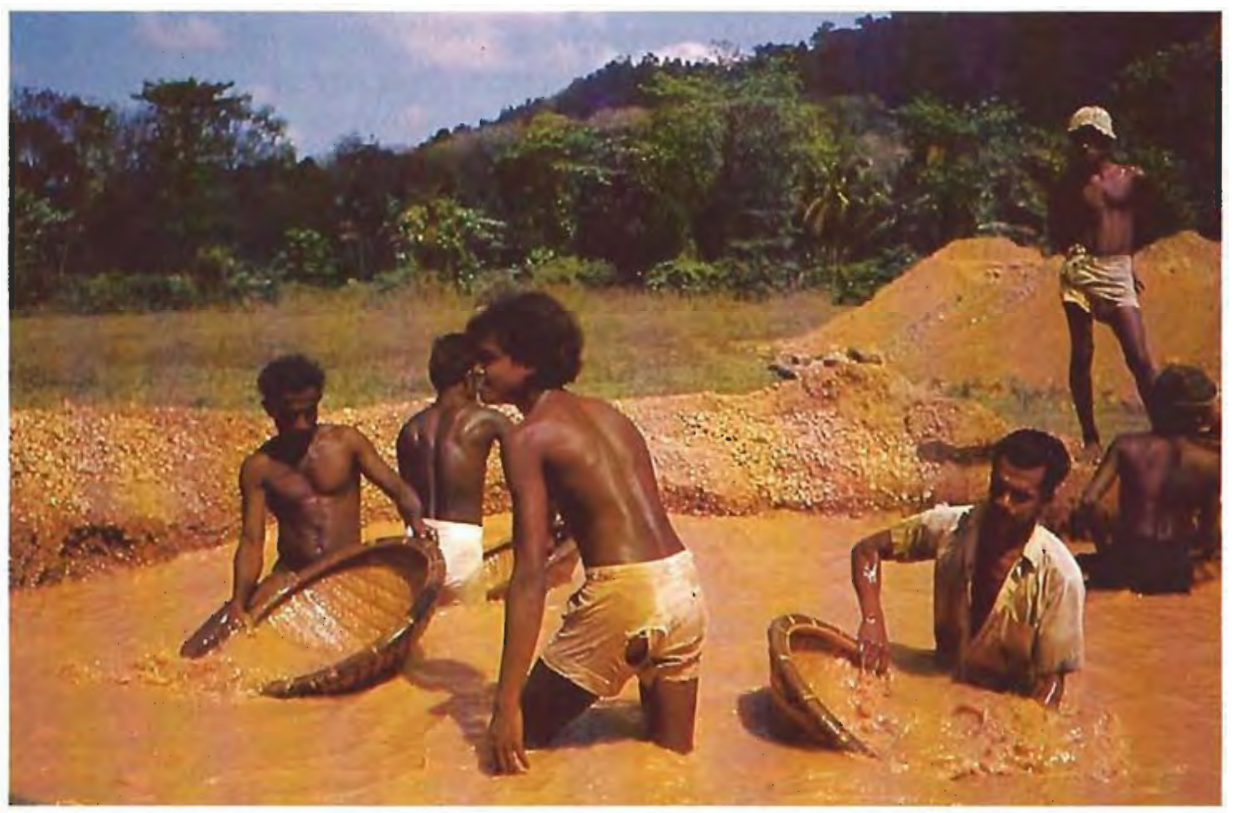

Figure 4. Washing of the "illam" in Ratnapura. 


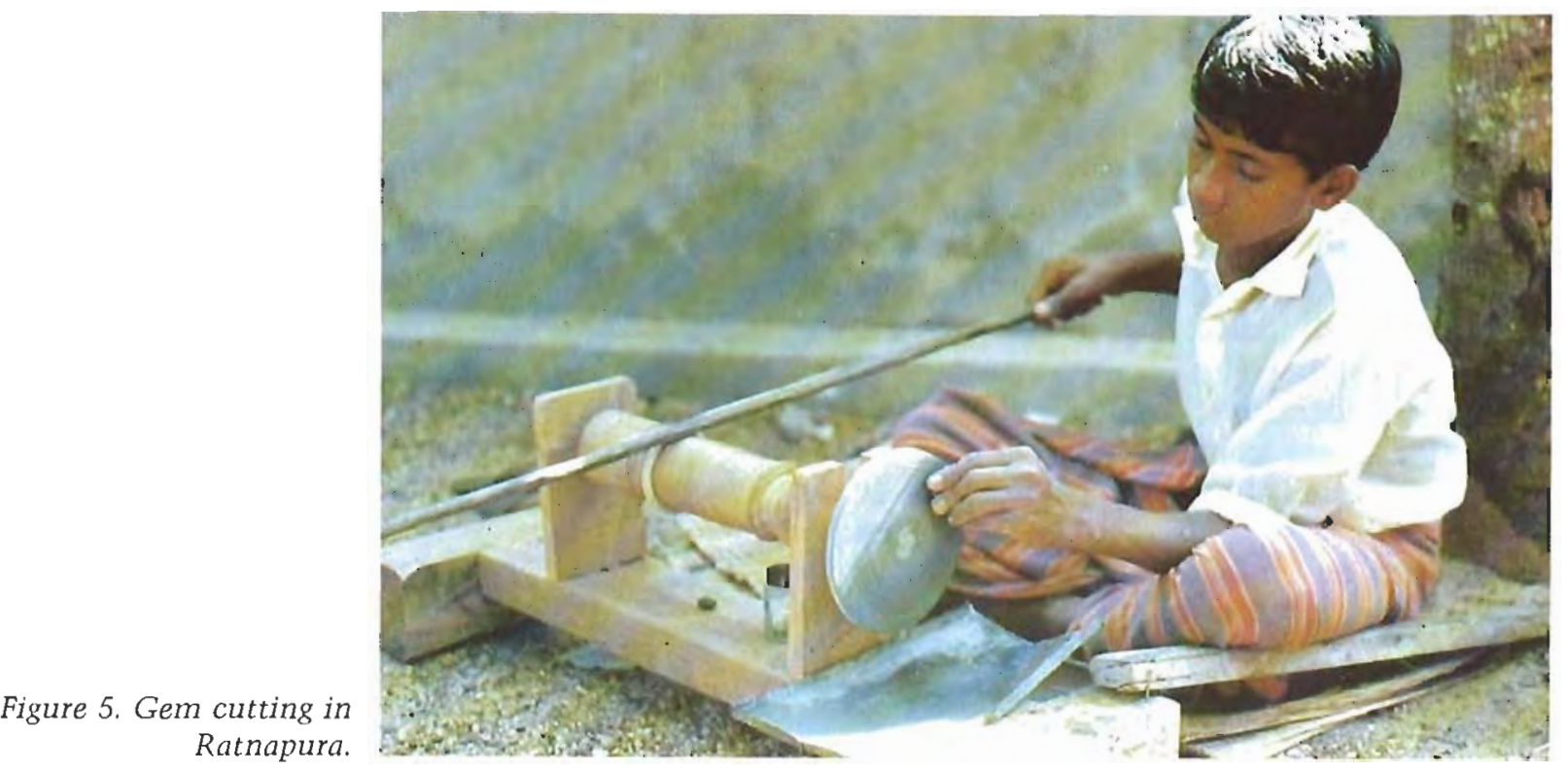

one end. The axle can be rotated with a cord that is moved to and fro with one hand while the stone is pressed against the wheel with the other (figure 5). Commonly, stones faceted in Sri Lanka are very irregular, as can be seen in figure 6 , which represents a parcel of Sri Lankan gems. With the emphasis on cutting for size rather than symmetry, much of the material is spoiled. For this reason, many stones cut in Sri Lanka are not suitable for sale in other countries without recutting.

Some years ago, machine cutting was introduced, mainly through the influence of the State Gem Corporation, and is now becoming very popular. It is a significant move in the right direction.

\section{IMPORTANT GEMSTONES}

Without doubt, blue sapphire is the most important gemstone found in Sri Lanka (figure 7). It is

Figure 6. Gemstones cut in Sri Lanka. For scale, the green zircon at the top left weighs $9.04 \mathrm{ct}$.

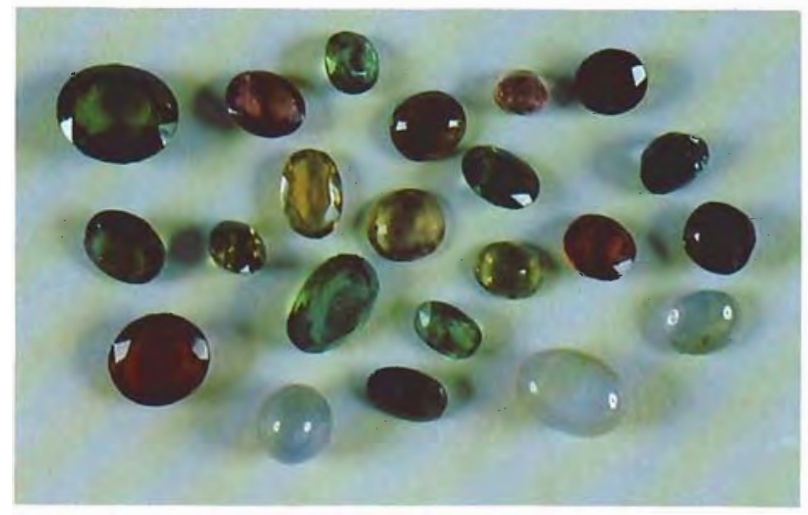

important not only commercially, but also for its unique beauty, especially its fine color. Although blue sapphire is found in a number of places in Sri Lanka, the occurrence at Rakwana in the Ratnapura district is particularly important, while the Tissamaharama area also promises to become a major source. A milky-white variety, suitable for treatment to obtain a fine blue color, is called "geuda" (Gunaratne, 1981).

The red corundum, or "Ceylon" ruby, is fairly common in most of the gem-bearing areas, but its color is never as saturated as that of the Burmese ruby. In fact, ruby from Sri Lanka tends to be pink rather than red.

Sri Lanka is one of the few sources for yellow sapphires (figure 8). They occur primarily in Balangoda. These stones typically range in hue from very pale to dark yellow. Some orange stones are occasionally seen as well. Deep-orange corundum, with the "color of the sunrise," is rare, and, therefore, highly prized. The name "padparadscha" has been applied to these rare stones.

Star corundum is common in Sri Lanka. Such stones occur in different colors, but bluish grey, pale violet, and milky white are most common. Star rubies and star sapphires of fine color are rare, but some important pieces have appeared (figure 9).

Another important Sri Lankan gem is chrysoberyl, especially the rare varieties alexandrite and cat's-eye. Good qualities of both varieties are scarce, and hence highly prized. Most alexandrites are rather clear and light green; their color range is moderate. The best cat's-eyes have a 


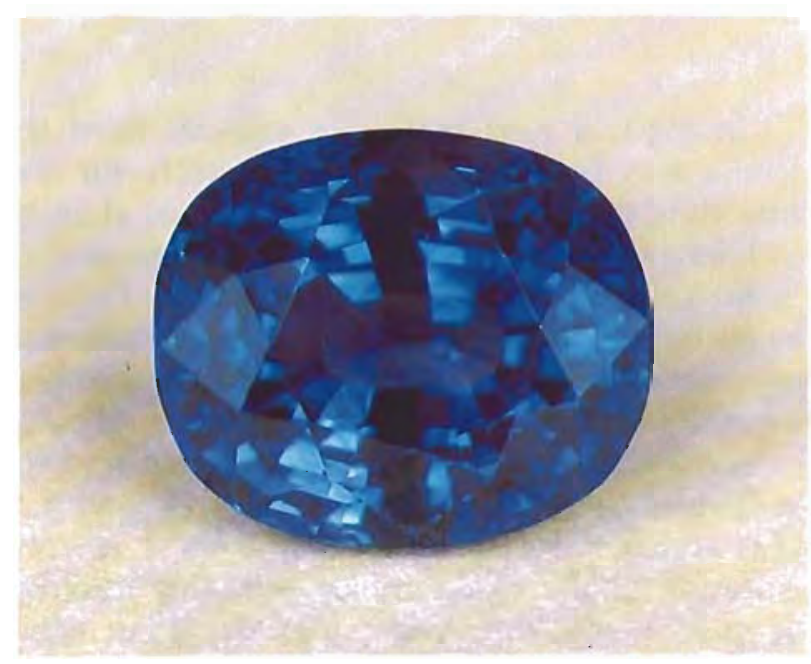

Figure 7. This 6.24-ct blue sapphire represents the fine color that comes from Sri Lanka. Photo by Tino Hammid.

honey-brown color, a sharp whitish chatoyancy, and are truly fine gemstones. Yellow to brown chrysoberyls also occur in Sri Lanka.

Among the garnets, two varieties are common: (1) a member of the pyrope-almandite series, and (2) the orange-brown grossular, known by its variety name hessonite. The pyropealmandite garnet has the characteristic rose-red color of "rhodolite," intermediate between pyrope and almandite, with a magnesium content that is higher than its iron content. Hessonite is mainly found in the southeastern part of the island, near Okkampitiya and Kataragama in particular.

Spinel occurs in different colors, especially purplish red and dark greenish blue. Iron-rich, dark green spinel from Sri Lanka is called ceylon-

Figure 8. Yellow sapphire from Sri Lanka, 1.42 ct. Photo by Tino Hammid.

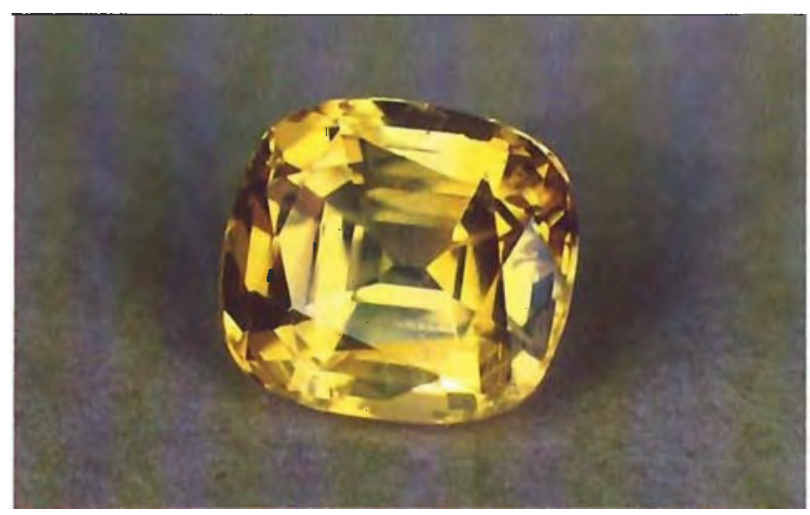

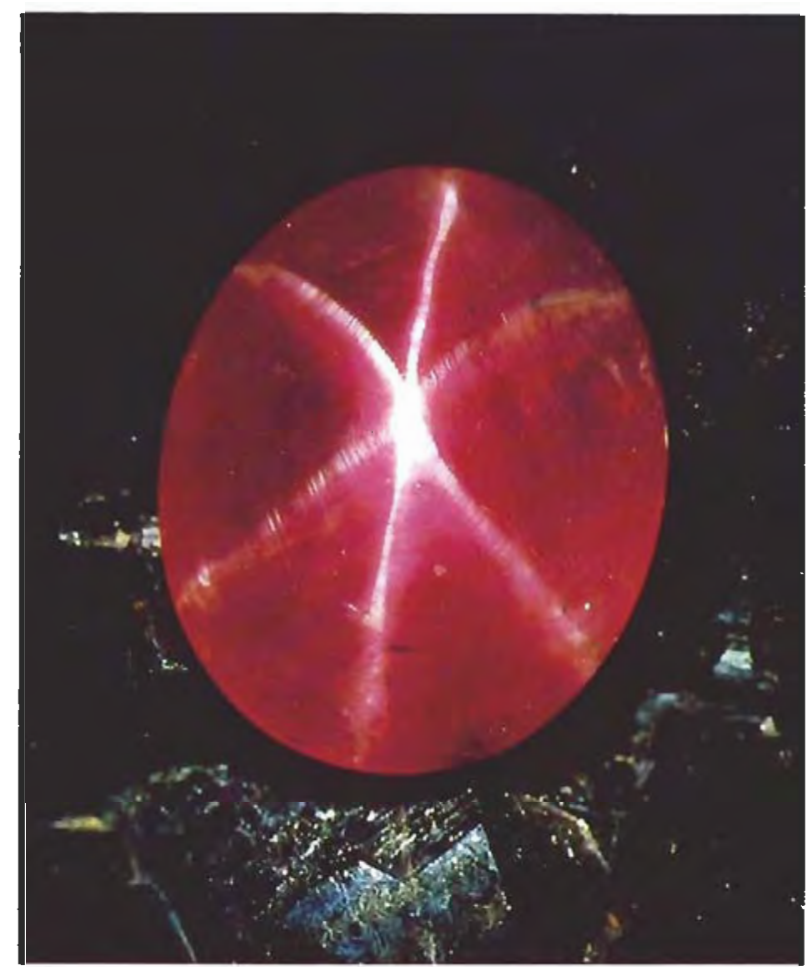

Figure 9. The 138.7-ct Rosser Reeves star ruby from Sri Lanka. Photo by Dane Penland, courtesy of the National Museum of Natural History, Smithsonian Institution, Washington, DC.

ite or pleonast, while a zinc-rich, blue spinel with the name gahno-spinel is also a typical Sri Lankan gemstone. Over the last four years, interest in spinels has increased enormously.

Although many colored gemstones in Sri Lanka are called tourmaline, this mineral seems to occur here in brown only and, in fact, is much less common than generally thought. Most socalled tourmalines are zircons which occur in many colors, such as reddish brown, yellowbrown, light to dark green, and olive green. The "low-type" zircons all have a green color, which may be considered characteristic for zircons from Sri Lanka.

Rather common are some quartz varieties such as rock crystal, amethyst, rose quartz, smoky quartz, and cat's-eye quartz. Stars occur mainly in rose-colored and greyish material; the asterism is caused by included sillimanite (Woensdrecht et al., 1980).

The island is one of the few sources of gemquality moonstone (figure 10). Stones with a fine blue sheen are now rare. Although the southwestern part of Sri Lanka, especially Meetiya- 


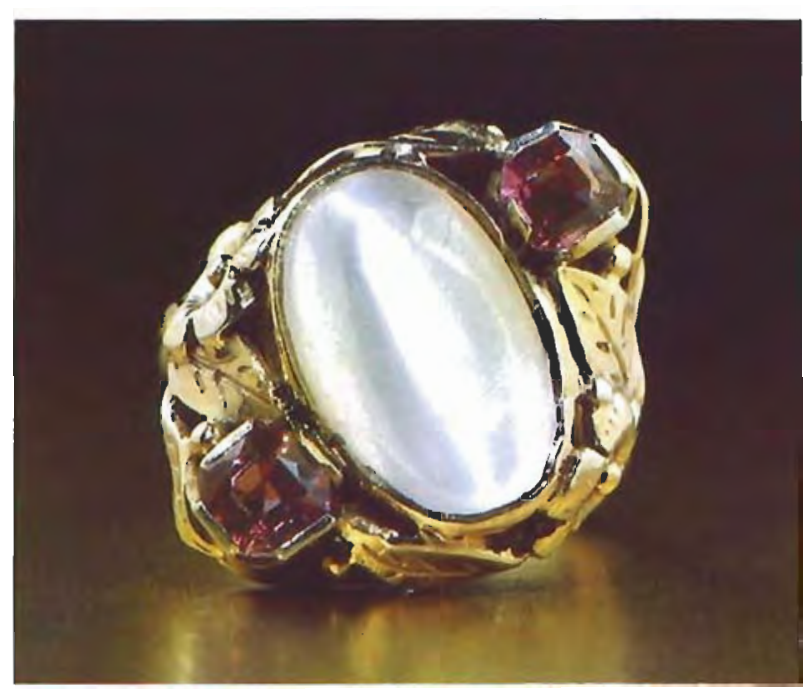

Figure 10. Cat's-eye moonstone, about $12 \mathrm{ct}$, from Sri Lanka. The two rhodolite garnets are also from Sri Lanka. Ring courtesy of Fannie $M$. Mann. Photo by Tino Hammid.

goda, is famous for this variety of feldspar, the mineral is also found in the Tissamaharama area.

Yellowish and colorless varieties of topaz occur in the Ratnapura district. In comparison with topaz from other countries, the Sri Lankan stones in general are not very attractive and, therefore, are less important.

\section{UNUSUAL GEMSTONES}

Unusual gems also occur in conjunction with the commercially important stones in several localities. Some of these, in fact, have not been found outside Sri Lanka and may be considered extremely rare.

Andalusite is occasionally found in the Ratnapura district and may be discovered in parcels of cut "tourmalines" because its hardness is very similar to that of tourmaline and zircon (which, as mentioned above, also appears in such parcels). Andalusite may be recognized by its extremely strong pleochroism in greenish-brown and red stones.

Apatite is one of the principal minerals in a carbonatite from Eppawala, which lies about 65 $\mathrm{km}$ northwest of Elahera. Brownish crystals up to about $1 \mathrm{~m}$ in length have been found, but they usually are not of gem quality. Some greenish to bluish-green apatites are found in Eheliyagoda and Balangoda; those found in the Ratnapura district are often of cutting quality.
In 1961, a new metamict mineral from Sri Lanka was mentioned in the literature for the first time (Gübelin, 1961). It was named ekanite in honor of Mr. F. L. D. Ekanayake, a gemologist in Sri Lanka at that time. Ekanite turned out to be extremely rare, and cut stones are encountered only occasionally. Thus far, Sri Lanka is the only known source of this calcium-thorium silicate.

Iolite (cordierite) is not an important jewelry gemstone, since its properties are very low, but it is an attractive stone for collectors. It is very common in the cordierite-gneisses that outcrop at many places throughout the island, but gemquality material is found only in the Ratnapura district. It is usually called "water sapphire" by the local inhabitants. Its very strong dichroism may be observed with the naked eye; the yellow is characteristic and unknown in blue sapphire.

Some years ago, kornerupine was regularly discovered in "tourmaline" parcels. Most often, the stone is green, but frequently some brown stones can be seen together with the green. About five years ago, cat's-eye kornerupine came on the market in Sri Lanka (Korevaar and Zwaan, 1977). Today, these cat's-eyes are considered common, although large stones are rare. They are said to originate in the Galle district, while the green stones without chatoyancy are from the Ratnapura district and from Matale in Central Province.

Sillimanite, or fibrolite, with a light blue color occasionally occurs in the Deniyaya district near Rakwana. A large gem-quality piece, recently found in Balangoda, is now in the collection of the State Gem Corporation.

A rare gem mineral that occurs at different places in the Ratnapura district is sinhalite, a magnesium-aluminum borate. Its properties bear some resemblance to those of peridot, and, in fact, many brown "peridots" in old collections have been identified as sinhalites on close examination. The material was described as a new mineral in 1952 (Claringbull and Hey, 1952). The stone may vary from almost colorless through light yellow to dark brown with increasing iron content.

Although sphene (or titanite) was mentioned many years ago as a possible gemstone from Sri Lanka (Gübelin, 1968), only very recently was gem-quality sphene reported from the Tissamaharama area (Zwaan and Arps, 1980; Zwaan, 1981). Because of its high optical properties, sphene is very attractive; yellow and brown are the predominant colors in sphene from Sri Lanka. 
A pale violet mineral, taaffeite, is found very rarely in parcels of spinel; it has similar properties but a distinct birefringence. Taaffeite was named in honor of its discoverer, Count Taaffe of Dublin, Ireland (Anderson, 1952). Thus far, only about 10 specimens have been reported; their exact source, somewhere in Sri Lanka, has not been identified.

Other unusual gemstones are regularly seen, for instance, a pale green spodumene from the Tissamaharama area (Zwaan, 1982). It is very likely that other rare or remarkable gemstones will be found in view of the complex geology and mineralization of the island's basement rocks.

\section{INCLUSIONS CHARACTERISTIC OF SRI LANKAN GEMS}

Examination by the author of the inclusions in different gemstones from Sri Lanka showed some of them to be characteristic of the locality, as described below.

With regard to solid inclusions, needle-like rutile crystals are often seen in almandite garnet (figure 11), sapphire, and other gemstones. The needles are arranged in three directions, making angles of about $60^{\circ}$ with each other; they usually are very long and run through the whole stone. These rutile inclusions often give a silky appearance to the stone, and they are responsible for asterism in many varieties of corundum.

Coarse-grained rutile also occurs in various garnets and may be present in cat's-eye kornerupine. Most often, the rutile has no distinct crystal faces, has a black color, and shows a high metallic luster.

In 1964, the author examined large idi-

Figure 11. Rutile crystals in almandite garnet from Sri Lanka. Polarized light, magnified 30x.

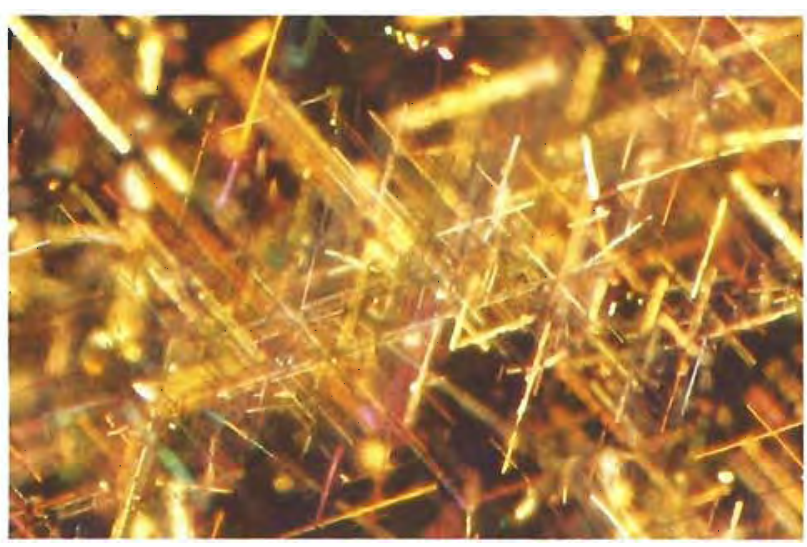

omorphic crystals in a blue spinel from the Ratnapura district (figure 12) which were found to be apatite (Zwaan, 1965). Since then, apatite crystals, formerly thought to be quartz crystals, are now recognized in garnet, corundum, and spinel. They seem to be diagnostic of the Sri Lankan origin of these species.

Inclusions of zircon crystals, surrounded by halos, are also very common in different gemstones, especially in garnet and corundum.

Hessonite garnets from Sri Lanka characteristically contain numerous, somewhat rounded crystal inclusions (figure 13) of both diopside and apatite. This occurrence is not strange because both are calcium minerals, as is hessonite garnet.

Liquid inclusions, resembling thumbprints and often called liquid feathers, are characteristic in

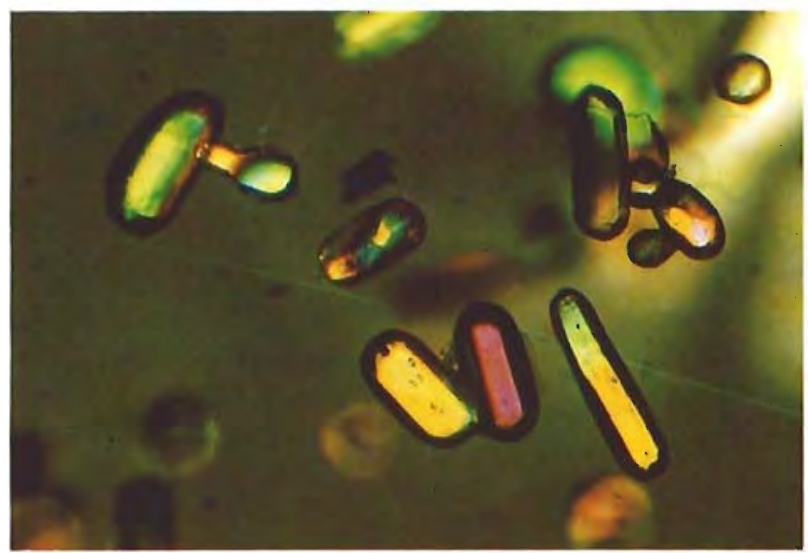

Figure 12. Apatite crystals in spinel from Sri Lanka. Polarized light, magnified $30 \times$.

Figure 13. Apatite and diopside crystals in hessonite garnet. Magnified $30 \times$.

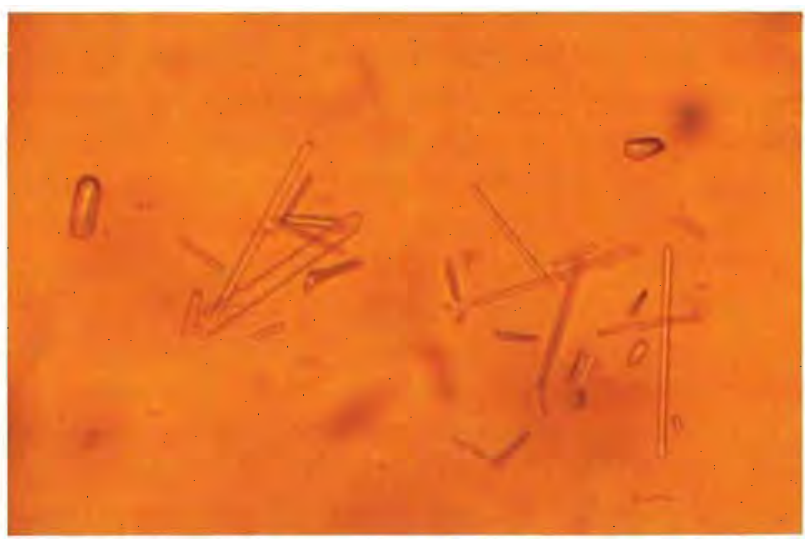




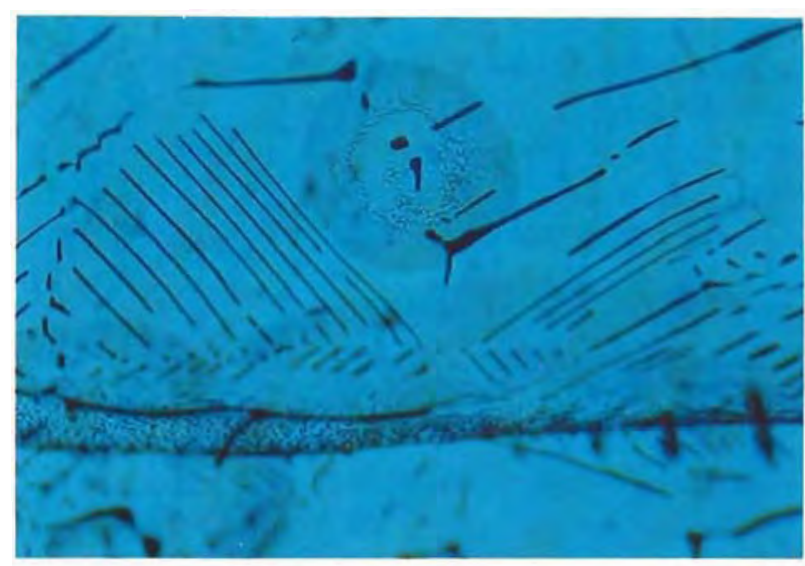

Figure 14. Liquid feathers in sapphire from Sri Lanka. Magnified $30 \times$.

many gemstones from Sri Lanka, including the corundums (figure 14).

Both these solid and liquid inclusions are of great importance when the origin of a gemstone has to be taken into consideration. From the author's investigations, they seem to be characteristic for Sri Lankan gemstones.

\section{PRODUCTION IN SRI LANKA}

As recently as the beginning of this century, little information was available on the amount and value of the gem material produced in Sri Lanka. Gem mining was thought to be limited to the Ratnapura district and the area near Galle. Not until 1923 was the discovery of good-quality material in Pelmadulla reported. But precise figures were impossible to obtain.

Even today, reliable figures are not available because many private miners sell their stones illegally to foreign buyers. During the author's first visit, in 1958, he was told that the annual figures reported by the government represented only about $10 \%$ of the real production. To provide some idea of the quantities involved during this period, in his 1965-1966 Administration Report, the director of the Geological Survey of Ceylon stated that exports of all types of gemstones amounted to a little over $61,000 \mathrm{ct}$. These export figures were, however, only from customs returns.

With the establishment of the State Gem Corporation (SGC) in the early 1970s (both to improve the country's gem industry and to help curb the large-scale smuggling of gems), the export figures improved considerably. In 1971, before the SGC had taken control, total sales of 3.4 million
Rs (1982 exchange: approximately 8 rupees per U.S. dollar) were reported. By 1973, after the SGC had established itself, the figure had ballooned to 152.9 million Rs, with a total production of $478,000 \mathrm{ct}$ of material. The most recent figure available to this author, for 1975 , was 188.9 million Rs. in gem exports. One can only assume that this number will continue to rise as the SGC furthers its efforts both to give some guidance to the gem industry and to search for new gem-bearing deposits.

\section{SUMMARY}

Sri Lanka is one of the most important sources in the world as far as the number of different gemstones it produces is concerned. It is remarkable that no explanation can be given as to where these gem minerals were formed originally, because they are all found in alluvial deposits.

The island consists almost entirely of Precambrian rocks, which may be divided into three groups: the Highland group, the Vijayan complex, and the Southwest group. Although gem minerals occur in different rocks of these series, few are of gem quality.

Historically, the most important gem-bearing area is the Ratnapura district in Sabaragamuwa Province. The gem minerals are concentrated in more-or-less horizontal levels at different depths in the alluvium. Similar deposits are found near Elahera, near Okkampitiya, and in the Tissamaharama area.

Mining methods are still primitive, as are the ways of washing and cutting the material. Machine cutting has been introduced, though, and significant improvements are anticipated. Very recently some machines were brought in to help with mining in the Balangoda area; in Pelmadulla, in particular, tunneling and river dredging for gems may be seen. Another mechanized mining project is going on in Samanalawewa at the moment. It may be expected that mining methods will be modernized rapidly, resulting in an enormous increase in the annual production.

Blue sapphire, ruby, yellow sapphire, and alexandrite and cat's-eye chrysoberyl are among the most important gemstones found in Sri Lanka. Also found in quantity are some garnets, spinel, and several varieties of quartz. A number of more unusual gemstones have also occurred in Sri Lanka. In fact, cat's-eye kornerupine is now very common. 
Typical inclusions in Sri Lankan gemstones are long, needle-shaped rutile crystals, arranged in three directions, that often cause a silky luster and are common in pyrope-almandite garnet and in corundum. Apatite crystals are often seen in garnet, corundum, and spinel, while zircon crystals surrounded by halos are also very common in garnet and corundum as well as in other Sri Lankan gems. Finally, liquid feathers are characteristic of many Sri Lankan gemstones.

Although production figures are not always reliable, they seem to be rising significantly now that the State Gem Corporation is supervising the industry. The efforts of the State Gem Corporation will undoubtedly result in the discovery of new gem-bearing deposits, as the country's supply of fine materials seems inexhaustable.

\section{REFERENCES}

Anderson B.W. (1952) Two new gemstones, taaffeite and sinhalite. Gems (4) Gemology, Vol. 7, No. 6, pp. 171-175.
Claringbull G.F., Hey M.H. (1952) Sinhalite (MgAlBO. $)$ a new mineral. Mineralogy Magazine, Vol. 29, pp. 841-849.

Gübelin E. (1961) Ekanite-another new metamict gem from Ceylon. Gems \&) Gemology, Vol. 10, No. 6, pp. 163-179.

Gübelin E. (1968) Die Edelsteine der Insel Ceylon. Gübelin, Lucerne.

Gunaratne H.S. (1976) On the occurrence of gem corundum in Kolonné. Journal of Gemmology, Vol. 15, No. 1, pp. 2930.

Gunaratne H.S. (1981) Geuda sapphires-their colouring elements and their reaction to heat. Journal of Gemmology, Vol. 17, No. 5, pp. 292-300.

Korevaar H.J., Zwaan P.C. (1977) Kornerupine cat's-eyes from Sri Lanka (Ceylon). Journal of Gemmology, Vol. 15, No. 5, pp. 225-230.

Woensdrecht C.F., Weibel M., Wessicken R. (1980) Star quartz asterism caused by sillimanite. Schweizerische Mineralogische und Petrographische Mitteilungen, Vol. 60, pp. 129132.

Zwaan P.C. (1965) Apatite crystals in a Ceylon spinel. Journal of Gemmology, Vol. 9, No. 12, pp. 434-440.

Zwaan P.C. (1981) Sphene, another gem mineral from Sri Lanka. Journal of Gemmology, Vol. 17, No. 8, pp. 624-635.

Zwaan P.C. (1982) Gemstones from the Tissamaharama area in Sri Lanka. Journal of the Gemmological Association of Japan, in press.

Zwaan P.C., Arps C.E.S. (1980) Sphene, Sri Lanka's newest gemstone. Scripta Geologica, No. 58.

\section{Complete Your Gems \& Gemology Collection Now}

A limited number of back issues of GEMS \& GEMOLOGY are currently available from stock. To help you complete your reference library, we are offering the following sets at special prices:

- A complete Four-issue Set of the 1981 volume, the colorful premier of our larger, expanded format. Now priced at $\$ 30.00$.

- A Collector's Set of the more than 130 back issues remaining for the period 1934-1980. Priced at \$350.00, this represents a savings of almost $\$ 50.00$.

Supplies of these special sets are limited, and will be filled on an as-available basis.

Single issues are priced as follows:

$\begin{array}{cr}\text { Pre-1981: } 1 \text { to } 3 \text { issues } & \$ 4.00 \text { each } \\ 4 \text { to } 11 \text { issues } & 3.50 \text { each } \\ 12+\text { issues } & 3.00 \text { each } \\ \text { Spring \& Winter } 1981^{*} & 5.00 \text { each }\end{array}$

Summer 1981 (limited stock) $\quad 10.00$ each

Fall 1981 available in complete 1981 sets only

All 1982 issues* $\quad 6.00$ each

All prices include book-rate postage to addresses inside the U.S. Postage to addresses outside the U.S. will be added; for these orders, please indicate whether you wish to have your copies shipped by air or surface mail.

*Discounts are available for orders of 10 or more of any of these single issues.

To order your sets or single issues, please contact:

Sally Thomas, Librarian

GEMS \& GEMOLOGY

1660 Stewart Street

Santa Monica, CA 90404

Telephone: (213) 829-2991, x 411

Please allow 4 to 6 weeks for delivery. 